\title{
The effect of acetylsalicylic acid dosed at bedtime on the anti-aggregation effect in patients with coronary heart disease and arterial hypertension: A randomized, controlled trial
}

\author{
Beata Krasińska ${ }^{1}$, Lech Paluszkiewicz ${ }^{2}$, Ewa Miciak-Lawicka ${ }^{1}$, Maciej Krasiński \\ Piotr Rzymski ${ }^{4}$, Andrzej Tykarski ${ }^{1}$, Zbigniew Krasiński ${ }^{5}$ \\ ${ }^{1}$ Department of Hypertension, Angiology and Internal Diseases, \\ Poznan University of Medical Sciences, Poznan, Poland \\ ${ }^{2}$ Department of Thoracic and Cardiovascular Surgery/Perioperative Diagnostics Bad Oeynhausen, \\ Heart and Diabetes Center NRW, Ruhr-University of Bochum, Germany \\ ${ }^{3}$ Student, Imperial College London School of Medicine, United Kingdom \\ ${ }^{4}$ Department of Environmental Medicine, Poznan University of Medical Sciences, Poznan, Poland \\ ${ }^{5}$ Department of General and Vascular Surgery, Poznan University of Medical Sciences, Poznan, Poland
}

\begin{abstract}
Background: Acetylsalicylic acid (ASA) is one of the basic drugs used in the secondary prevention of coronary artery disease (CAD), and in most cases it is taken in the morning in one daily dose. It is suggested that the morning peak of platelet aggregation is responsible for the occurrence of myocardial infarctions and strokes. Hence, the aim of the study was to observe the effect of ASA (morning vs. evening) dosing on the anti-aggregative effect of platelets in patients with $C A D$ and arterial hypertension $(A H)$. Methods: The study involved 175 patients with $C A D$ and $A H$. Patients were randomly assigned to one of two study groups, taking ASA in the morning or in the evening. The patients had two visits, one baseline and another after 3 months from changing the time of ASA dosage. The platelet aggregation was determined using the VerifyNow analyzer.

Results: In the ASA evening group, a significant reduction in platelet aggregation was obtained. In the ASA morning group, a significant difference in response to ASA was observed, depending on sex. In men, the reactivity of platelets decreased, but in women it increased.

Conclusions: In the group of patients with CAD and AH, bedtime ASA dosing is associated with a significant reduction in platelet aggregation. The response to ASA may differ between sexes. The benefit gained by changing the drug administration from the morning to the evening is greater in women. (Cardiol J 2019; 26, 6: 727-735)
\end{abstract}

Key words: acetylsalicylic acid, platelet aggregation, bedtime administration, chronotherapy, circadian rhythm, gender-dependence, randomized controlled trial

\section{Introduction}

The functioning of the human body is subjected to cyclical variability in the form of oscillation of physiological phenomena called biological rhythms [1]. These include circadian rhythms that can significantly affect the function of the cardiovascular system [2]. It is suggested that changes in circadian rhythms in the coagulation system are one of the causes of sudden deaths, myocardial

Address for correspondence: Beata Krasińska, MD, PhD, Prof. UM, Department of Hypertension, Angiology and Internal Disease, Poznan University of Medical Sciences, ul. Długa 1/2, 61-848 Poznań, Poland, tel: +48 61 8549090, fax: +48 618549083 , e-mail: beata.bkrasinska@gmail.com

Received: 5.09.2018 Accepted: 11.11 .2018 
infarctions (MI), and ischemic strokes that occur more often when switching from the sleep phase to the awakening [2]. It has been shown that during the morning there is an increase in blood pressure, episodes of sudden cardiac death, unstable angina, and rupture of the aortic dissecting aneurysm are more frequent [3-6]. In the Framingham, ISAM, and TIMI II studies the incidence of MI was 3-fold higher in the morning than in the late evening [7-9]. A registry of 45,000 patients showed a higher incidence of ST-segment elevation MI heart attacks in the morning (41\%) compared to the afternoon and night hours (respectively, $32 \%$ and $26 \%, \mathrm{p}<$ $<0.001$ ) [10]. The mechanisms of these phenomena are not fully understood; it is suggested that one of the reasons may be a morning increase in blood viscosity due to platelet hyperaggregation and decreased fibrinolytic activity, leading to an increased risk of thromboembolic events [11-14]. Therefore, it would be useful to use the chronotherapy principles in acetylsalicylic acid (ASA) therapy to reduce the incidence of acute cardiovascular events that occur in the morning. Chronotherapy involves adjusting the concentration and potency of the drug over time in accordance with biological circadian rhythms $[15,16]$. To date, few papers about the influence of taking ASA on the morning peak of platelet activity have been published. ASA belongs to the basic drugs used in the secondary prevention of coronary artery disease (CAD), and in most cases it is taken in one daily dose in the morning hours $[17,18]$. The epidemiological data and clinical observations described above prompted interest in changing the dose of ASA from a morning dose to bedtime. The aim of the present study was to observe the effect of ASA (morning vs. evening) dosing on the antiaggregative effect of platelets in a high-risk group of cardiovascular patients.

\section{Methods}

The study included 200 patients, aged 59.8 years, with diagnosed $\mathrm{CAD}$ and arterial hypertension (AH), who were taking ASA $75 \mathrm{mg} /$ day in a single antiplatelet therapy, and who were admitted to the Department of Hypertension. Eventually the inclusion criteria were met by 175 patients (59 women and 116 men). The recruitment period was 21 months (from May 2015 to January 2017). Patients with CAD and AH were randomly assigned to one of two study groups taking ASA in the morning (58 patients) or in the evening (56 patients). The third group, which was the control, included 61 patients with $\mathrm{AH}$, without $\mathrm{CAD}$, and not taking any antiplatelet drugs (Table 1). The study was approved by the Bioethics Committee of Karol Marcinkowski University of Medical Sciences in Poznan (Resolution No. 373/15). Each participant signed informed consent to participate in the study, which was a form approved by the Bioethical Committee. Exclusion criteria for the study were as follows: secondary hypertension, MI and stroke within 6 months prior to the study, chronic heart failure - New York Heart Association (NYHA) III and IV, chronic kidney disease (glomerular filtration rate $<30 \mathrm{~mL} / \mathrm{min}$ ), addiction to alcohol or psychotropic substances, and active cancer. Additional exclusion criteria for the study group were: confirmed hypersensitivity to ASA, history of bleeding due to ASA, taking clopidogrel or other antiplatelet agents, hemorrhagic diathesis, active gastric and/or duodenal ulcer disease, and hypersensitivity to an active substance: ASA, other salicylates or any component of the drug, using non-steroidal anti-inflammatory drugs (NSAID). The exclusion criterion for the control group was the use of ASA preparations in the preceding 30 days. There were no changes in the concomitant treatment (lipid-lowering, antihypertensive, and antidiabetic), and no NSAID were taken during the study.

\section{Scheme of the study}

Patients enrolled in the study had two visits in accordance with a prescribed treatment schedule (Fig. 1). On the first qualifying visit (Visit 1), the patients were admitted to the ward where laboratory and imaging examinations with the assessment of the severity of platelet aggregation using the VerifyNow Aspirin Test and randomization regarding the inclusion of ASA morning or evening took place. After 3 months of ASA therapy, Visit 2 was administered, during which the examinations from the initial visit were repeated.

\section{VerifyNow Aspirin Test}

During a single whole blood sample collection, $2.2 \mathrm{~mL}$ vacuum collection tubes with $3.2 \%$ sodium citrate were used, together with 21-gauge needles as recommended by the manufacturer.

VerifyNow Aspirin assay contains lyophilised fibrinogen-coated beads and a platelet agonist arachidonic acid. It is designed to measure platelet function based on the ability of activated platelets to bind fibrinogen. Fibrinogen-coated microparticles aggregate in whole blood in proportion to the number of unblocked platelet glycoprotein (GP) IIb/IIIa receptors. Light transmittance increases 
Table 1. Patient demographic characteristics

\begin{tabular}{|c|c|c|c|c|}
\hline & \multicolumn{2}{|c|}{ Acetylsalicylic acid } & \multirow{2}{*}{$\begin{array}{l}\text { Control group } \\
(\mathrm{n}=61)\end{array}$} & \multirow[t]{2}{*}{$\mathbf{P}$} \\
\hline & Morning $(n=58)$ & Evening $(n=56)$ & & \\
\hline Female/male & $19 / 39$ & $19 / 37$ & $21 / 40$ & $>0.05^{*}$ \\
\hline Smokers/non-smokers & $14 / 44$ & $17 / 39$ & $17 / 44$ & $>0.05^{*}$ \\
\hline Age [years] & $59.8 \pm 7.6$ & $60.3 \pm 7.1$ & $59.9 \pm 7.1$ & $>0.05^{* *}$ \\
\hline Weight [kg] & $84.4 \pm 9.7$ & $84.9 \pm 12.9$ & $84.1 \pm 10.1$ & $>0.05^{* *}$ \\
\hline Height $[\mathrm{m}]$ & $1.69 \pm 0.1$ & $1.69 \pm 0.1$ & $1.69 \pm 0.1$ & $>0.05^{* *}$ \\
\hline BMI $\left[\mathrm{kg} / \mathrm{m}^{2}\right]$ & $29.52 \pm 3.95$ & $29.50 \pm 4.4$ & $29.52 \pm 4.1$ & $>0.05^{* *}$ \\
\hline Waist [cm] & $93.1 \pm 11.1$ & $92.5 \pm 11.4$ & $93.7 \pm 11.6$ & $>0.05^{* *}$ \\
\hline Hip [cm] & $105.2 \pm 10.2$ & $105.3 \pm 12.3$ & $105.2 \pm 10.6$ & $>0.05^{* *}$ \\
\hline Waist to hip ratio & $0.88 \pm 0.05$ & $0.87 \pm 0.06$ & $0.89 \pm 0.08$ & $>0.05^{* *}$ \\
\hline Systolic BP [mmHg] & $145.5 \pm 5.0$ & $145.2 \pm 6.7$ & $145.1 \pm 5.2$ & $>0.05^{* *}$ \\
\hline Diastolic BP [mmHg] & $88.8 \pm 4.0$ & $88.8 \pm 5.3$ & $89.0 \pm 5.5$ & $>0.05^{* *}$ \\
\hline
\end{tabular}

Data are shown as number or mean \pm standard deviation. Statistics: ${ }^{*}$ Chi-square; ${ }^{* * K r u s k a l-W a l l i s ~ A N O V A ; ~ B M I ~ — ~ b o d y ~ m a s s ~ i n d e x ; ~ B P ~ — ~}$ blood pressure

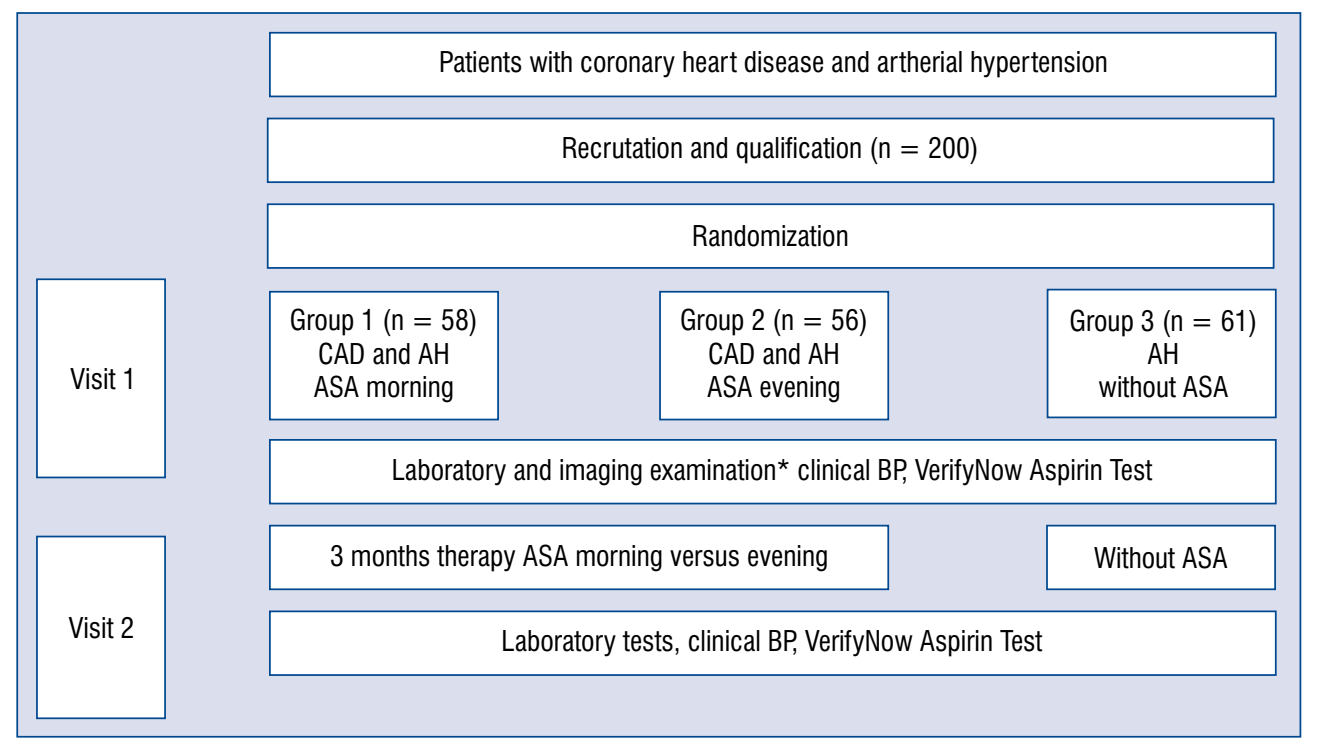

Figure 1. Scheme of the study. *In each group: Laboratory tests, abdominal ultrasound examination, abdominal computed tomography scan, Doppler ultrasound of renal arteries, clinical blood pressure ( $3 \times / 24 \mathrm{~h})$, electrocardiography, echocardiography, weight, and body mass index assessment; $\mathrm{AH}$ - arterial hypertension; ASA — acetylsalicylic acid; $\mathrm{BP}$ - blood pressure; CAD — coronary artery disease

as activated platelets bind and aggregate fibrinogen-coated beads. The instrument measures this change in the optical signal caused by aggregation. Assay results are reported as Aspirin Reaction Units (ARU), which are calculated as a function of the rate of aggregation. ARU values $<550$ indicate an effective result of ASA, while ARU values $>550$ indicate no effect of the drug.

\section{Statistical analysis}

Statistical analyses were performed with Statistica, version 12.5 (StatSoft, USA). Since the tested data had not met the assumption of Gaussian distribution (evaluated with Shapiro-Wilk method), non-parametric methods were applied. The Kruskal-Wallis ANOVA test was used for evaluation of the differences in parameters between the three 
Table 2. Patient clinical data of the groups.

\begin{tabular}{|c|c|c|c|}
\hline & \multicolumn{2}{|c|}{ Acetylsalicylic acid } & \multirow{2}{*}{$\begin{array}{l}\text { Control } \\
\text { group }\end{array}$} \\
\hline & Morning & Evening & \\
\hline $\begin{array}{l}\text { Coronary heart } \\
\text { disease }\end{array}$ & 58 & 56 & 0 \\
\hline Arterial hypertension & 58 & 56 & 61 \\
\hline Diabetes mellitus & 15 & 17 & 14 \\
\hline Metabolic syndrome & 21 & 20 & 22 \\
\hline $\begin{array}{l}\text { History of myocardial } \\
\text { infarction }\end{array}$ & 12 & 13 & 0 \\
\hline $\begin{array}{l}\text { Previous ischemic } \\
\text { stroke or transient } \\
\text { cerebral ischemia }\end{array}$ & 5 & 6 & 0 \\
\hline $\begin{array}{l}\text { History of coronary } \\
\text { artery bypass surgery }\end{array}$ & 8 & 9 & 0 \\
\hline $\begin{array}{l}\text { History of coronary } \\
\text { angioplasty }\end{array}$ & 38 & 37 & 0 \\
\hline Hyperlipidemia & 58 & 56 & 61 \\
\hline $\begin{array}{l}\text { Atherosclerosis of } \\
\text { the lower limbs }\end{array}$ & 7 & 6 & 5 \\
\hline $\begin{array}{l}\text { Chronic obstructive } \\
\text { pulmonary disease }\end{array}$ & 6 & 7 & 5 \\
\hline Thyroid disease & 4 & 5 & 6 \\
\hline
\end{tabular}

groups. Changes in parameters in the individual groups during the first and second visit were analyzed using the Wilcoxon signed-rank test - the parametric equivalent of the T-test for related variables. Frequencies, expressed on a nominal scale, were analyzed based on the Pearson $\chi^{2}$ test. A p-value $<0.05$ was considered significant.

\section{Results}

Table 1 presents the basic clinical and demographic data of the group of patients studied. Selected parameters: body mass index (BMI), weight, waist, hips did not change significantly in any of the studied groups or in the control group, between groups and between Visits 1 and $2(\mathrm{p}>0.05$, Wilcoxon signed-rank test). Table 2 presents the data from the interviewed population, including concomitant diseases. Table 3 summarizes the most important drugs (antihypertensive, hypolipemic and antidiabetic) taken by the patients. What is important, is that there was no significant difference between the groups in the amount of the drugs administered during the therapy and there was no change of drugs during the study. In all patients, a qualitative measurement of platelet aggregation was also performed using the VerifyNow
Table 3. Drugs used in groups studied.

\begin{tabular}{|c|c|c|c|}
\hline & \multicolumn{3}{|c|}{ Acetylsalicylic acid Control } \\
\hline & Morning & Evening & \\
\hline Acetylsalicylic acid & $58^{a}$ & $56^{a}$ & $0^{\mathrm{b}}$ \\
\hline $\begin{array}{l}\text { Anti-hypertensive } \\
\text { drugs }\end{array}$ & $2.58^{a}$ & $2.66^{a}$ & $2.57^{a}$ \\
\hline$\beta$-blockers & $58^{a}$ & $56^{a}$ & $53^{a}$ \\
\hline $\begin{array}{l}\text { Angiotensin-converting } \\
\text { enzyme inhibitors }\end{array}$ & $40^{\mathrm{a}}$ & $34^{\mathrm{a}}$ & $40^{\mathrm{a}}$ \\
\hline $\begin{array}{l}\text { Angiotensin II receptor } \\
\text { antagonists }\end{array}$ & $18^{\mathrm{a}}$ & $22^{\mathrm{a}}$ & $21^{\mathrm{a}}$ \\
\hline Calcium antagonists & $22^{\mathrm{a}}$ & 25 & 25 \\
\hline $\begin{array}{l}\text { Diuretics/aldosterone } \\
\text { antagonists }\end{array}$ & $13^{\mathrm{a}}$ & 12 & $16^{\mathrm{a}}$ \\
\hline $\begin{array}{l}\text { Concomitant lipid- } \\
\text { lowering therapy }\end{array}$ & $58^{\mathrm{a}}$ & $56^{a}$ & $58^{\mathrm{a}}$ \\
\hline $\begin{array}{l}\text { Concomitant } \\
\text { antidiabetic therapy } \\
\text { (metformin) }\end{array}$ & $15^{\mathrm{a}}$ & $17^{\mathrm{a}}$ & $14^{\mathrm{a}}$ \\
\hline Proton pump inhibitors & $47^{a}$ & $45^{\mathrm{a}}$ & $42^{\mathrm{a}}$ \\
\hline
\end{tabular}

${ }^{a}$, bDifferent letters given in the upper index indicate the occurrence of statistical differences in the values of a given parameter between the three groups (Kruskal-Wallis ANOVA, $p<0.05$ )

Aspirin Test. Figure 2 presents the results of the examination of inhibition of platelet aggregation in individual groups during the first and second visit.

The result of the Aspirin VerifyNow Test was given as the severity of platelet aggregation in ARU. At the baseline visit, the inhibition of aggregation in ARUs did not differ between the groups and was $489.01 \pm 73.0$ in the morning ASA group and $488.16 \pm 83.0$ in the evening ASA group. In the control group, which did not take ASA, the result was $638.31 \pm 15.9$ ARU. Only in the ASA evening group, a significant reduction in platelet aggregation of 28 ARUs was obtained compared to the morning ASA group $(460.10 \pm 82.3 \mathrm{~h}$ vs. $487.62 \pm 77.4 \mathrm{~h}$ in the morning; $\mathrm{p}<0.05$ ).

Figure 3 shows changes in ARU on Visit 2, depending on sex (p-value applies to Mann-Whitney $\mathrm{U}$ test), compared to Visit 1 . In the group that took ASA in the morning, a significant difference in response to ASA was observed, depending on sex. In men, the reactivity of platelets decreased by $9.5 \pm 44.3 \mathrm{ARU}$, and in women, conversely, it increased by $13.9 \pm 48.2$ ARU. The size of this decline in the ASA group in the morning in men was lower than in the ASA group in the evening. There was no correlation between age, BMI waist to hip ratio of the patients, and change in 


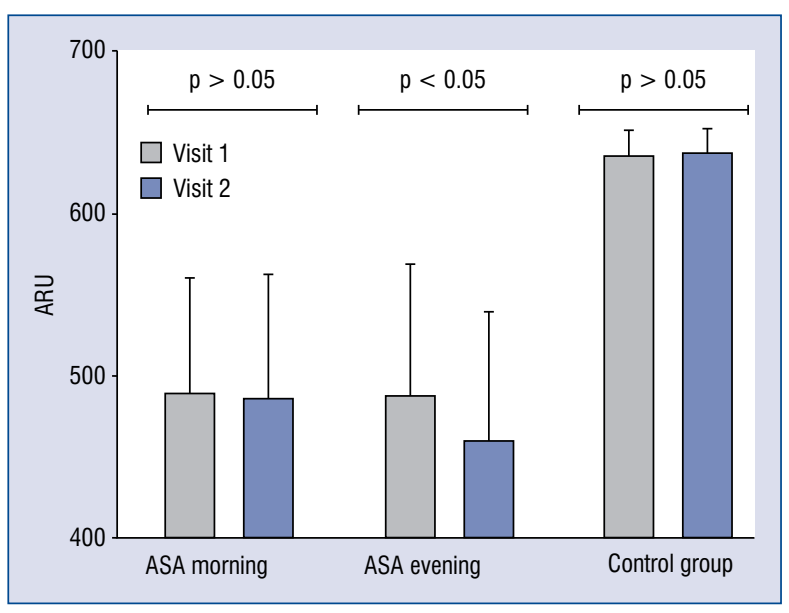

Figure 2. Change in Aspirin Reaction Units (ARU) between Visit 1 and 2 in groups studied ( $p$-value refers to Wilcoxon-signed rank test); ASA - acetylsalicylic acid.

platelet aggregation after the change of dosage to bedtime. The changes in laboratory tests were also noted. Only in the ASA evening group was there a decrease in the number of platelets and an increase in uric acid concentration. There were no changes in other laboratory parameters between groups (Table 4 ).

\section{Discussion}

On the basis of data from epidemiological studies, it has been shown that circadian rhythms can affect both the physiology and pathology in the cardiovascular system [19, 20]. In the early morning hours, a higher incidence of MIs, sudden cardiac death, ventricular malignant arrhythmia, stroke, and acute aortic dissection is observed [21-24]. MIs, which occur between 6 a.m. and 12 noon, cause $21 \%$ more damage to the myocardium, which is a factor that worsens prognosis [19,25]. Aggregation of platelets and the level of aggregation markers have their circadian rhythm peaking between 6 a.m. and 12 noon [26, 27]. The severity of platelet aggregation in the morning may be associated with an increase in the number of acute coronary syndromes [28]. It seems that it is important to look for new ways to properly inhibit platelet aggregation in the morning. One of these methods could be an evening administration of ASA. The aim of the study was to compare the effect of ASA on platelet aggregation, depending on the time of drug administration in the morning versus in the evening, in patients with $\mathrm{CAD}$ and first- and second-degree $\mathrm{AH}$, according to

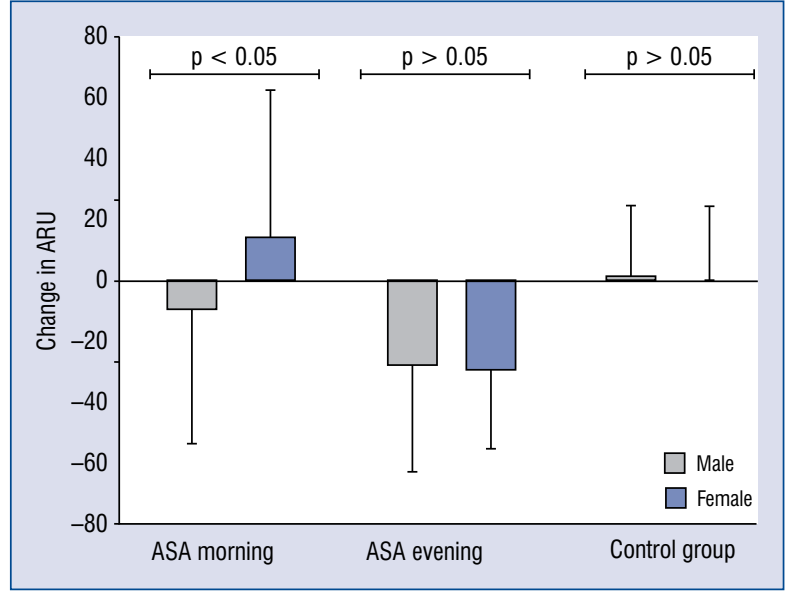

Figure 3. Change in Aspirin Reaction Units (ARU) at Visit 2 in relation to Visit 1 in the groups studied in relation to patient sex ( $p$-value refers to Mann-Whitney $U$ test); ASA - acetylsalicylic acid.

European Society of Hypertension (ESH)/European Society of Cardiology (ESC) 2013 [29-31].

In the current observation, in the evening ASA group, a significant reduction in platelet aggregation of $28 \mathrm{ARU}$ was obtained compared to the morning ASA group $(460.10 \pm 82.3 \mathrm{~h}$ vs. $487.62 \pm$ $\pm 77.4 \mathrm{~h}$ in the morning; $\mathrm{p}<0.05)$. At the baseline visit, the results of inhibition of aggregation in ARUs did not differ between the groups and were $489.01 \pm 73.0$ in the morning ASA group and $488.16 \pm 83.0$ in the evening ASA group. This is in line with the results obtained by Bonten et al. [32]. In their study of 290 patients with normal blood pressure or mild $\mathrm{AH}$, they showed that ASA given in the evening reduced platelet reactivity by an average of 22 ARU compared to the morning ASA group [32]. In another study, in a small group of healthy volunteers, the same researchers marked cyclooxygenase-1 (COX-1)-dependent platelet activity (using the VerifyNow Aspirin Test) and the level of thromboxane B2 (STxB2). They showed reduced platelet activity of 23 ARU platelet in VerifyNow Aspirin Test and a reduction in TXB2 by $1.7 \mathrm{ng} / \mathrm{mL}$ in those who took ASA at bedtime compared to those who took ASA in the morning. This confirms the effect of a low-dose ASA taken at bedtime on the reduction of COX-1-dependent platelet activity in healthy people [25, 33].

Acetylsalicylic acid is rapidly and almost completely absorbed in the stomach and duodenum by passive diffusion. Due to the short half-life, which is $2-3 \mathrm{~h}$, ASA inhibits about $90 \%$ of platelets that are present in the plasma when the drug is taken. 
Table 4. Laboratory tests of the groups studied at Visit 1 and Visit 2.

\begin{tabular}{|c|c|c|c|c|}
\hline & & \multicolumn{2}{|c|}{ Acetylsalicylic acid } & \multirow[t]{2}{*}{ Control group } \\
\hline & & Morning & Evening & \\
\hline \multirow[t]{3}{*}{ Hemoglobin [mmol/L] } & Visit 1 & $8.8 \pm 0.74^{a}$ & $8.7 \pm 0.58^{a}$ & $8.9 \pm 0.73^{a}$ \\
\hline & Visit 2 & $8.8 \pm 0.7^{\mathrm{a}}$ & $8.6 \pm 0.7^{a}$ & $8.9 \pm 0.7^{\mathrm{a}}$ \\
\hline & P (Wilcoxon) & $>0.05$ & $>0.05$ & $>0.05$ \\
\hline \multirow[t]{3}{*}{ Platelets $\left[10^{-9} / \mathrm{L}\right]$} & Visit 1 & $225.7 \pm 54.3^{\mathrm{a}}$ & $227.6 \pm 56.9^{a}$ & $224.5 \pm 61.1^{\mathrm{a}}$ \\
\hline & Visit 2 & $226.9 \pm 36.8^{a}$ & $197.9 \pm 41.5^{b}$ & $226.0 \pm 60.2^{\mathrm{a}}$ \\
\hline & P (Wilcoxon) & $>0.05$ & $<0.05$ & $>0.05$ \\
\hline \multirow[t]{3}{*}{$\mathrm{Na}[\mathrm{mmol} / \mathrm{L}]$} & Visit 1 & $141.2 \pm 2.5^{\mathrm{a}}$ & $141.1 \pm 2.2^{\mathrm{a}}$ & $141.7 \pm 2.1^{\mathrm{a}}$ \\
\hline & Visit 2 & $141.0 \pm 2.1^{\mathrm{a}}$ & $140.9 \pm 2.2^{\mathrm{a}}$ & $141.9 \pm 2.3^{\mathrm{a}}$ \\
\hline & P (Wilcoxon) & $>0.05$ & $>0.05$ & $>0.05$ \\
\hline \multirow[t]{3}{*}{$\mathrm{K}[\mathrm{mmol} / \mathrm{L}]$} & Visit 1 & $4.3 \pm 0.45^{a}$ & $4.3 \pm 0.4^{\mathrm{a}}$ & $4.2 \pm 0.4^{\mathrm{a}}$ \\
\hline & Visit 2 & $4.3 \pm 0.3^{\mathrm{a}}$ & $4.3 \pm 0.4^{a, b}$ & $4.2 \pm 0.3^{b}$ \\
\hline & P (Wilcoxon) & $>0.05$ & $>0.05$ & $>0.05$ \\
\hline \multirow[t]{3}{*}{ Total cholesterol [mmol/L] } & Visit 1 & $4.8 \pm 1.1^{\mathrm{a}}$ & $4.7 \pm 1.0^{\mathrm{a}}$ & $4.7 \pm 0.9^{\mathrm{a}}$ \\
\hline & Visit 2 & $4.7 \pm 0.9^{\mathrm{a}}$ & $4.8 \pm 1.1^{\mathrm{a}}$ & $4.4 \pm 0.9^{\mathrm{a}}$ \\
\hline & P (Wilcoxon) & $>0.05$ & $>0.05$ & $>0.05$ \\
\hline \multirow[t]{3}{*}{ LDL-C [mmol/L] } & Visit 1 & $1.3 \pm 0.4^{\mathrm{a}}$ & $1.4 \pm 0.5^{\mathrm{a}}$ & $1.4 \pm 0.5^{\mathrm{a}}$ \\
\hline & Visit 2 & $1.5 \pm 0.5^{\mathrm{a}}$ & $1.5 \pm 0.6^{\mathrm{a}}$ & $1.7 \pm 0.6^{\mathrm{a}}$ \\
\hline & P (Wilcoxon) & $>0.05$ & $>0.05$ & $>0.05$ \\
\hline \multirow[t]{3}{*}{ HDL-C [mmol/L] } & Visit 1 & $2.6 \pm 1.0^{\mathrm{a}}$ & $2.5 \pm 0.9^{a}$ & $2.5 \pm 0.7^{\mathrm{a}}$ \\
\hline & Visit 2 & $2.5 \pm 0.8^{\mathrm{a}}$ & $2.4 \pm 0.8^{\mathrm{a}}$ & $2.5 \pm 0.7^{\mathrm{a}}$ \\
\hline & P (Wilcoxon) & $>0.05$ & $>0.05$ & $>0.05$ \\
\hline \multirow[t]{3}{*}{ Triglicerydes [mmol/L] } & Visit 1 & $1.6 \pm 0.5^{\mathrm{a}}$ & $1.6 \pm 0.4^{\mathrm{a}}$ & $1.5 \pm 0.8^{\mathrm{a}}$ \\
\hline & Visit 2 & $1.6 \pm 0.4^{\mathrm{a}}$ & $1.5 \pm 0.5^{\mathrm{a}}$ & $1.7 \pm 0.8^{\mathrm{a}}$ \\
\hline & P (Wilcoxon) & $>0.05$ & $>0.05$ & $>0.05$ \\
\hline \multirow[t]{3}{*}{ GFR $\left[\mathrm{mL} / \mathrm{min} / 1.73 \mathrm{~m}^{2}\right]$} & Visit 1 & $80.4 \pm 9.7^{a}$ & $79.3 \pm 12.6^{\mathrm{a}}$ & $78.8 \pm 11.7^{\mathrm{a}}$ \\
\hline & Visit 2 & $80.6 \pm 9.0^{\mathrm{a}}$ & $82.9 \pm 8.9^{a}$ & $79.7 \pm 9.9^{a}$ \\
\hline & P (Wilcoxon) & $>0.05$ & $>0.05$ & $>0.05$ \\
\hline \multirow[t]{3}{*}{ Serum creatinine $[\mu \mathrm{mol} / L]$} & Visit 1 & $82.2 \pm 5.1^{\mathrm{a}}$ & $82.2 \pm 5.1^{\mathrm{a}}$ & $81.6 \pm 5.2^{\mathrm{a}}$ \\
\hline & Visit 2 & $79.4 \pm 15.4^{a}$ & $82.9 \pm 12.0^{a}$ & $82.3 \pm 10.9^{a}$ \\
\hline & P (Wilcoxon) & $>0.05$ & $>0.05$ & $>0.05$ \\
\hline \multirow[t]{3}{*}{ Glucose $[\mathrm{mmol} / \mathrm{L}]$} & Visit 1 & $5.2 \pm 0.9^{\mathrm{a}}$ & $5.2 \pm 0.7^{\mathrm{a}}$ & $5.2 \pm 0.6^{a}$ \\
\hline & Visit 2 & $5.1 \pm 0.7^{\mathrm{a}}$ & $5.3 \pm 0.7^{\mathrm{a}}$ & $5.1 \pm 0.5^{\mathrm{a}}$ \\
\hline & P (Wilcoxon) & $>0.05$ & $>0.05$ & $>0.05$ \\
\hline \multirow[t]{3}{*}{ Urid acid [umol/l] } & Visit 1 & $331.9 \pm 101^{a}$ & $334.3 \pm 99^{a}$ & $330.7 \pm 97^{a}$ \\
\hline & Visit 2 & $332.7 \pm 105^{a}$ & $379.1 \pm 71^{b}$ & $328.9 \pm 99^{a}$ \\
\hline & P (Wilcoxon) & $>0.05$ & $<0.05$ & $>0.05$ \\
\hline \multirow[t]{3}{*}{ CRP [mg/L] } & Visit 1 & $2.0 \pm 1.8^{\mathrm{a}}$ & $1.9 \pm 0.9^{a}$ & $1.9 \pm 0.8^{\mathrm{a}}$ \\
\hline & Visit 2 & $2.1 \pm 1.6^{\mathrm{a}}$ & $2.1 \pm 1.0^{\mathrm{a}}$ & $1.8 \pm 0.8^{\mathrm{a}}$ \\
\hline & P (Wilcoxon) & $>0.05$ & $>0.05$ & $>0.05$ \\
\hline
\end{tabular}

${ }^{a, b}$ Different letters given in the upper index indicate the occurrence of statistical differences in the values of a given parameter between the three groups (Kruskal-Wallis ANOVA, $\mathrm{p}<0.05$ ); CRP - C-reactive protein; GFR - glomerular filtration rate; HDL-C - high density lipoprotein cholesterol; LDL-C - low density lipoprotein cholesterol 
It should be remembered that physiologically, at all the times, new and uninhibited plates are released into the blood, which constitute about $10 \%$ of the total number. The release of new platelets may be greater in people with vascular disease [34-36]. It has been shown that in up to $25 \%$ of patients, inhibition of platelets by ASA decreases gradually within $24 \mathrm{~h}$ after its administration [18, 37]. In his work, Kirszbacher et al. [38] confirmed that the time of taking ASA can affect the incidence of cardiovascular events and can change the effectiveness of prophylaxis. If the drug is given in the morning, it was obvious that the highest plasma drug levels occurred after the morning peak of the incidence of a thromboembolic event. Moreover, the method of morning ASA administration has a lower protective value for the prevention of cardiovascular events at night and early in the morning, when the lack of physical activity further promotes platelet aggregation and ischemia. In contrast, the highest plasma concentration of ASA administered late in the evening reaches its maximum before the peak of thromboembolic events [38-40]. Henry et al. [41] evaluated the biological effect of low-dose ASA in 150 patients with CAD. Platelet aggregation increased gradually after taking the drug in the second hour after only $4.7 \%$ and after $12 \mathrm{~h}$ in $11 \%$ of patients, respectively. These results correlated with elevated levels of inflammatory markers, smoking, and diabetes. The authors suggested that administration of ASA once per $24 \mathrm{~h}$ (regardless of dose, $75 \mathrm{mg}$ or $>100 \mathrm{mg}$ ) does not provide stable 24-h antiplatelet protection in a significant proportion of patients with CAD [41]. Studies by other authors have clearly demonstrated that the antiplatelet effect of ASA decreases within 24 $\mathrm{h}$ after a single administration of the drug. The observation referred to 100 patients with diabetes and 73 non-diabetic patients. In both groups, the production of thromboxane (TXA2) was significantly inhibited after $12 \mathrm{~h}$ and was followed by a slow recovery of platelet activity. Greater body weight was the only independent predictor of faster return of COX-1 activity, but only in non-diabetic subjects. It has been shown that dosing ASA once a day may cause COX-1 activity to return more rapidly and may result in incomplete TAX2 inhibition. In contrast, $100 \mathrm{mg}$ ASA taken twice a day caused complete TAX2 blocking in both groups. The authors concluded that insufficient inhibition of TAX2 can be easily corrected by changing the diagram from once a day to twice a day [37]. This mechanism, due to limitations and assumptions of this paper, has not been analyzed.
The findings of the present study are in line with previously conducted trials by Bonten et al. $[32,33]$, and they confirm that bedtime ASA intake has a better effect on decreasing the platelet reactivity than an intake on awakening. However, the present study also demonstrated the significant gender-dependence difference in response to ASA administrated in the morning. In men, the reactivity of platelets decreased by $9.5 \pm 44.3$ ARU, whereas in women it increased by $13.9 \pm$ \pm 48.2 ARU. In men, the size of this decline in the ASA morning group was lower than in the ASA evening group. It is known that the antiplatelet effect of ASA gradually decreases within $24 \mathrm{~h}$ after administration [41]. In this study, platelet activity during Visit 2 was measured in the morning, which is $12 \mathrm{~h}$ and $24 \mathrm{~h}$ after taking ASA, in the group receiving the drug in the evening and in the morning, respectively. The striking difference between men and women in the latter group is probably due to the overall higher platelet reactivity in women [42]. Therefore COX-1 dependent platelet inhibition may be shorter than in men. Therefore, morning intake of ASA in women is not only ineffective in response to platelets, but it can also cause an adverse response, which is particularly important in patients with a high risk of cardiovascular disease. This fact could be an additional argument to dose ASA in the evening because its activity is then independent of sex. However, this requires further observation.

\section{Conclusions}

1. In the group of patients with ischemic heart disease and hypertension, dosing ASA at bedtime compared to dosing the morning is associated with a significant reduction in platelet aggregation, which is determined using the VerifyNow analyzer.

2. The response to ASA in patients with ischemic heart disease and hypertension may differ from one sex to another. The research suggests that the benefit gained by changing the drug administration from the morning to the evening is greater in women.

\section{Conflict of interest: None declared}

\section{References}

1. Smolensky MH, Portaluppi F. Chronopharmacology and chronotherapy of cardiovascular medications: relevance to prevention and treatment of coronary heart disease. Am Heart J. 1999; 137(4 Pt 2): S14-S24, indexed in Pubmed: 10097242. 
2. Reinberg A. Human chronobiology and chronopharmacology. Isr J Med Sci. 1976; 12(8): 770-779, indexed in Pubmed: 977285.

3. Cohen DL, Townsend RR. Is it morning blood pressure surge or extreme nocturnal dipping that accounts for the increased stroke risk in the morning waking hours? J Clin Hypertens (Greenwich). 2014; 16(12): 847, doi: 10.1111/jch.12438, indexed in Pubmed: 25365938.

4. Sumiyoshi M, Kojima S, Arima M, et al. Circadian, weekly, and seasonal variation at the onset of acute aortic dissection. Am J Cardiol. 2002; 89(5): 619-623, indexed in Pubmed: 11867056.

5. Behar S, Reicher-Reiss H, Goldbourt U, et al. Circadian variation in pain onset in unstable angina pectoris. Am J Cardiol. 1991; 67(1): 91-93, indexed in Pubmed: 1986511.

6. Cohen MC, Rohtla KM, Lavery CE, et al. Meta-analysis of the morning excess of acute myocardial infarction and sudden cardiac death. Am J Cardiol. 1997; 79(11): 1512-1516, indexed in Pubmed: 9185643.

7. Willich S, Levy D, Rocco M, et al. Circadian variation in the incidence of sudden cardiac death in the framingham heart study population. Am J Cardiol. 1987; 60(10): 801-806, doi: 10.1016/0002-9149(87)91027-7.

8. Willich SN, Linderer T, Wegscheider K, et al. Increased morning incidence of myocardial infarction in the ISAM Study: absence with prior beta-adrenergic blockade. ISAM Study Group. Circulation. 1989; 80(4): 853-858, doi: 10.1161/01.cir.80.4.853.

9. Guerci AD, Ross RS. TIMI II and the role of angioplasty in acute myocardial infarction. N Engl J Med. 1989; 320(10): 663-665, doi: 10.1056/NEJM198903093201009, indexed in Pubmed: 2521918.

10. Mogabgab O, Wiviott SD, Antman EM, et al. Relation between time of symptom onset of ST-segment elevation myocardial infarction and patient baseline characteristics: from the National Cardiovascular Data Registry. Clin Cardiol. 2013; 36(4): 222-227, doi: 10.1002/clc.12101, indexed in Pubmed: 23520015.

11. Kapiotis S. Morning hypercoagulability and hypofibrinolysis. Diurnal variations in circulating activated factor VII, prothrombin fragment F1+2, and plasmin-plasmin inhibitor complex. Circulation. 1997; 96(1): 19-21.

12. Ehrly AM, Jung G. Circadian rhythm of human blood viscosity. Biorheology. 1973; 10(4): 577-583, indexed in Pubmed: 4783690.

13. Haus E. Chronobiology of hemostasis and inferences for the chronotherapy of coagulation disorders and thrombosis prevention. Adv Drug Deliv Rev. 2007; 59(9-10): 966-984, doi: 10.1016/j. addr.2006.11.002, indexed in Pubmed: 17822804.

14. Ündar L, Türkay C, Korkmaz L. Circadian variation in circulating platelet aggregates. Annals of Medicine. 2009; 21(6): 429-433, doi: 10.3109/07853898909149234.

15. Noel H, Saunders E, Smolensky M. Hypertension, chronotherapy, and patient management. Nurse Pract. 2000; 25(Suppl): 2-10, doi: 10.1097/00006205-200003001-00001.

16. Andrys-Wawrzyniak I, Jabłecka A. Chronobiologia, chronofarmakologia i ich miejsce w medycynie. Farmacja Współczesna. 2008; 1: 156-168.

17. Chapman AR, Rushworth GF, Leslie SJ. Aspirin desensitization in patients undergoing percutaneous coronary intervention: a survey of current practice. Cardiol J. 2013; 20(2): 134-138, doi: 10.5603/CJ.2013.0025, indexed in Pubmed: 23558870.

18. Würtz M. Aspirin in coronary artery disease: an appraisal of functions and limitations. Dan Med J. 2015; 62(4): B5011, indexed in Pubmed: 25872543.

19. Suárez-Barrientos A, López-Romero P, Vivas D, et al. Circadian variations of infarct size in acute myocardial infarction. Heart. 2011; 97(12): 970-976, doi: 10.1136/hrt.2010.212621, indexed in Pubmed: 21525526.
20. Richards AM, Nicholls MG, Espiner EA, et al. Diurnal patterns of blood pressure, heart rate and vasoactive hormones in normal man. Clin Exp Hypertens A. 1986; 8(2): 153-166, indexed in Pubmed: 3521953.

21. Morning peak in the incidence of myocardial infarction: experience in the ISIS-2 trial. ISIS-2 (Second International Study of Infarct Survival) Collaborative Group. Eur Heart J. 1992; 13(5): 594-598, indexed in Pubmed: 1618199.

22. Elliott WJ. Circadian variation in the timing of stroke onset: a meta-analysis. Stroke. 1998; 29(5): 992-996, indexed in Pubmed: 9596248.

23. Englund A, Behrens S, Wegscheider K, et al. Circadian variation of malignant ventricular arrhythmias in patients with ischemic and nonischemic heart disease after cardioverter defibrillator implantation. European 7219 Jewel Investigators. J Am Coll Cardiol. 1999; 34(5): 1560-1568, indexed in Pubmed: 10551707.

24. Manfredini R, Boari B, Gallerani M, et al. Chronobiology of rupture and dissection of aortic aneurysms. J Vasc Surg. 2004; 40(2): 382-388, doi: 10.1016/j.jvs.2004.04.019, indexed in Pubmed: 15297840 .

25. Franco E, Núñez-Gil IJ, Vivas D, et al. Heart failure and nonST-segment elevation myocardial infarction: a review for a widespread situation. Eur J Intern Med. 2011; 22(6): 533-540, doi: 10.1016/j.ejim.2011.07.009, indexed in Pubmed: 22075276.

26. Tofler GH, Brezinski D, Schafer AI, et al. Concurrent morning increase in platelet aggregability and the risk of myocardial infarction and sudden cardiac death. N Engl J Med. 1987; 316(24): 1514-1518, doi: 10.1056/NEJM198706113162405, indexed in Pubmed: 3587281.

27. Scheer FA, Michelson AD, Frelinger AL, et al. The human endogenous circadian system causes greatest platelet activation during the biological morning independent of behaviors. PLoS One. 2011; 6(9): e24549, doi: 10.1371/journal.pone.0024549, indexed in Pubmed: 21931750.

28. Mogabgab O, Wiviott SD, Cannon CP, et al. Circadian variation of stent thrombosis and the effect of more robust platelet inhibition: a post hoc analysis of the TRITON-TIMI 38 trial. J Cardiovasc Pharmacol Ther. 2013; 18(6): 555-559, doi: 10.1177/1074248413497534, indexed in Pubmed: 24064010.

29. Perk J. [European Guidelines on Cardiovascular Disease Prevention in Clinical Practice (version 2012). The Fifth Joint Task Force of the European Society of Cardiology and other societies on cardiovascular disease prevention in clinical practice (constituted by representatives of nine societies and by invited experts)]. G Ital Cardiol (Rome). 2013; 14(5): 328-392.

30. Mancia G. 2013 ESH/ESC Guidelines for the management of arterial hypertension: the Task Force for the management of arterial hypertension of the European Society of Hypertension (ESH) and of the European Society of Cardiology (ESC). J Hypertens. 2013; 31(7): 1281-357.

31. Tykarski A, Narkiewicz K, Gaciong Z, et al. 2015 guidelines for the management of hypertension. Recommendations of the Polish Society of Hypertension - short version. Kardiol Pol. 2015; 73(8): 676-700, doi: 10.5603/KP.2015.0157, indexed in Pubmed: 26304155.

32. Bonten TN, Snoep JD, Assendelft WJJ, et al. Time-dependent effects of aspirin on blood pressure and morning platelet reactivity: a randomized cross-over trial. Hypertension. 2015; 65(4): 743-750, doi: 10.1161/HYPERTENSIONAHA.114.04980, indexed in Pubmed: 25691622.

33. Bonten TN, Saris A, van Oostrom MJ, et al. Effect of aspirin intake at bedtime versus on awakening on circadian rhythm 
of platelet reactivity. A randomised cross-over trial. Thromb Haemost. 2014; 112(6): 1209-1218, doi: 10.1160/TH14-05-0453, indexed in Pubmed: 25208590.

34. Grove EL, Hvas AM, Mortensen SB, et al. Effect of platelet turnover on whole blood platelet aggregation in patients with coronary artery disease. J Thromb Haemost. 2011; 9(1): 185-191, doi: 10.1111/j.15387836.2010.04115.x, indexed in Pubmed: 20955349.

35. Postula M, Janicki PK, Rosiak M, et al. Association of plasma concentrations of salicylic acid and high on ASA platelet reactivity in type 2 diabetes patients. Cardiol J. 2013; 20(2): 170-177, doi: 10.5603/CJ.2013.0030, indexed in Pubmed: 23558875.

36. Perneby C, Wallén NH, Rooney C, et al. Dose- and time-dependent antiplatelet effects of aspirin. Thromb Haemost. 2006; 95(4): 652-658, indexed in Pubmed: 16601836.

37. Rocca B, Santilli F, Pitocco D, et al. The recovery of platelet cyclooxygenase activity explains interindividual variability in responsiveness to low-dose aspirin in patients with and without diabetes. J Thromb Haemost. 2012; 10(7): 1220-1230, doi: 10.1111/j.15387836.2012.04723.x, indexed in Pubmed: 22471290.
38. Kriszbacher I, Ajtay Z, Koppán M, et al. Can the time of taking aspirin influence the frequency of cardiovascular events? Am J Cardiol. 2005; 96(4): 608-610, doi: 10.1016/j.amjcard.2005.03.068, indexed in Pubmed: 16098324.

39. Cornélissen G, Halberg F, Prikryl P, et al. Prophylactic aspirin treatment: the merits of timing. International Womb-to-Tomb Chronome Study Group. JAMA. 1991; 266(22): 3128-3129, indexed in Pubmed: 1956095.

40. Kriszbacher, I., M. Koppan, and J. Bodis, Aspirin for stroke prevention taken in the evening? Stroke, 2004. 35(12): 2760-1; author reply: 2761-2.

41. Henry P, Vermillet A, Boval B, et al. 24-hour time-dependent aspirin efficacy in patients with stable coronary artery disease. Thromb Haemost. 2011; 105(2): 336-344, doi: 10.1160/TH10-020082, indexed in Pubmed: 21136023.

42. Breet NJ, Sluman MA, van Berkel MA, et al. Effect of gender difference on platelet reactivity. Neth Heart J. 2011; 19(11): 451-457, doi: 10.1007/s12471-011-0189-y, indexed in Pubmed: 21901505. 